\title{
Association between Mannose-Binding Lectin 2 Gene Polymorphism and Liver Fibrosis in Patients with Chronic Viral Hepatitis

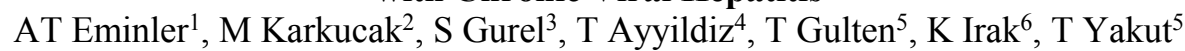

\begin{abstract}
Objective: Mannose-Binding Lectin (MBL) has become a popular molecule in investigations on basic and clinical Gastroenterology and contributed to new approaches to the understanding of infectious and immune diseases associated with intestine and liver. The aim of the present study was to investigate the association between codon 54 polymorphisms in MBL2 gene coding MBL and predisposition to fibrosis in patients with viral Hepatitis B and C.
\end{abstract}

Methods: One hundred patients with chronic hepatitis (70 hepatitis B, 30 hepatitis C) who underwent liver biopsy and 100 healthy controls with no known chronic disease were included in the study. Patients in both viral hepatitis groups were divided into two groups according to their fibrosis scores with Ishak scoring system. The polymerase chain reaction-restriction fragment length polymorphism (PCR-RFLP) method was applied to determine the MBL2 codon 54 polymorphism. For the statistical analysis, the level of significance was set at $\mathrm{P}<0.05$.

Results: No significant differences in allele frequencies for any polymorphism were observed between patients and controls, although the $G$ allele was more frequent in the patient groups $(p>0.05)$. In the comparison in terms of $\mathrm{G}$ and $\mathrm{A}$ alleles between two groups, hepatitis B patients in Group-II (group with high fibrosis score) were found to have a significantly higher frequency of A alleles $(\mathrm{p}=0.027)$.

Conclusion: Although it is accepted that MBL2 polymorphism play a part in the course of $\mathrm{HBV}$ and $\mathrm{HCV}$ infections, larger studies investigating the relation between MBL2 polymorphism and disease progression and treatment are required.

Keywords: Fibrosis, hepatitis B, hepatitis C, MBL2 gene, polymorphism

From: ${ }^{1}$ Department of Gastroenterology, Sakarya University Faculty of Medicine, Sakarya, Turkey. ${ }^{2}$ Department of Medical Genetics, Sakarya University Training and Research Hospital, Sakarya, Turkey. ${ }^{3}$ Department of Gastroenterology, Uludag University Faculty of Medicine, Bursa, Turkey. ${ }^{4}$ Department of Gastroenterology, Ondokuz Mayis University Faculty of Medicine, Samsun, Turkey. ${ }^{5}$ Department of Medical Genetics, Uludag University Faculty of Medicine, Bursa, Turkey. ${ }^{6}$ Department of Gastroenterology, Kanuni Sultan Suleyman Training and Research Hospital, Istanbul, Turkey.

Correspondence: Dr M Karkucak, Department of Medical Genetics, Sakarya University Training and Research Hospital, 54000, Sakarya, Turkey. E-mail: mutlukarkucak@hotmail.com 


\section{INTRODUCTION}

Mannose-Binding Lectin (MBL), which is the one of innate immune system pattern recognising molecules, is a $\mathrm{C}$ type serum Lectin. It is a molecule that recognising major soluble patterns and which plays a significant role in the innate immunity by activating the complement pathway synthesized by the hepatocytes and phagocytosis(1,2). Its specific structure consists of the collagenous region and Lectin domain(3) Lectin contributes to the elimination of many microorganisms through complement pathway and opsonophagocytosis(4). Due to genomic polymorphisms in $M B L 2$ gene, there are differences in the serum MBL levels of people(5). Therefore, polymorphisms influencing serum levels of protein may lead to infections and predisposition to autoimmune diseases.

MBL is coded by MBL2 gene located on chromosome 10 and containing four exons. It is the only collection with the ability to activate complement system(1). Recently, it has become a popular subject in investigations on basic and clinical Gastroenterology and contributed to new approaches to the understanding of infectious and immune diseases associated with intestine and liver.

For $M B L 2$ codon 54 polymorphism, normal allele is called $\mathrm{G}$, and the variant allele is called A. The aim of the present study was to investigate the association between codon 54 polymorphisms in MBL2 gene coding MBL and predisposition to fibrosis in patients with viral Hepatitis B and C.

\section{SUBJECTS AND METHOD}

\section{Study subjects}

One hundred patients with chronic hepatitis (70 hepatitis B, 30 hepatitis C) who underwent liver biopsy in Gastroenterology Department of Uludağ University Faculty of Medicine and 
100 healthy controls with no known chronic disease were included in the study. Patients in both viral hepatitis groups were divided into two groups according to their fibrosis scores with Ishak scoring system(6). Those with the fibrosis score of 3 or lower were defined as Group-I; and those with a score of 4 or over as Group-II. The study was conducted in accordance with the Declaration of Helsinki and Principles for Good Clinical Practice and was approved by the local Ethics Committee ( 2009-12/96). Prior to the study inclusion, all patients read and signed the informed consent form. After signing an informed consent from each patient, a 2 $\mathrm{ml}$ of blood taken into EDTA tubes for the $M B L 2$ gene polymorphisms and were stored at $20^{\circ} \mathrm{C}$.

\section{DNA Extraction and Genotyping}

Blood samples from both the patient and the control groups were taken in EDTA tubes. DNA isolation was performed according to the procedures of the Dr. Zeydanlı (DZ) DNA isolation kit, and samples were stored at $-20^{\circ} \mathrm{C}$ until PCR.

MBL2 gene codon 54 polymorphism was determined using the polymerase chain reactionrestriction fragment length polymorphism (PCR-RFLP) method. For the MBL2 gene codon 54 polymorphism, forward 5'- TAGGACAGAGGGCATGCTC -3 ' and reverse 5'CAGGCAGTTtCCTCTGGAAGG -3' primers were used(7). To identify the MBL2 gene codon 54 polymorphism among the products, the Ban I enzyme was used. In the analysis conducted in $2 \%$ agarose gel after cutting the enzyme, genotypes were determined as follows: if the $349 \mathrm{bp}$ PCR product from the MBL2 gene was cut into two distinct products of $260 \mathrm{bp}$ and $89 \mathrm{bp}$, then the genotype was identified as $\mathrm{G} / \mathrm{G}$; if three distinct products were formed as $349 \mathrm{bp}, 260 \mathrm{bp}$ and $89 \mathrm{bp}$, then the genotype was identified as G/A; and if the product was $349 \mathrm{bp}$ then the genotype was identified as A/A. 


\section{Statistical analysis}

The data were analyzed using SPSS 13.0 software (IBM Corp., NY, USA). The data was recorded in \pm standard deviations. The Mann-Whitney $U$ test used to compare the age between the two groups. The Chi-Square $(\chi 2)$ test was used to compare genotypes. P values smaller than 0.05 were accepted as being statistically significant.

\section{RESULTS}

In this study, among the 100 cases in the patient group (53 males and 47 females), the mean age was $43.98 \pm 12.75$, and among the 100 cases in the control group (54 males and 46 females), the average age was $43 \pm 12.46$. There was no difference in the age and gender between the patient and control groups.

Regarding the codon 54 polymorphism of the MBL2 gene in the study, among the 100 chronic Hepatitis B and C patients, 73 were identified with the G/G genotype, 16 with the G/A genotype, and 11 with the A/A genotype. Among the 100 individuals in the control group, 63 were identified with the G/G genotype, 19 with genotype G/A and 18 with the A/A genotype. Using the subjects with the $\mathrm{G} / \mathrm{G}$ homozygote genotype as a reference group, we found no association between the G/A and G/A genotypes and the risk of chronic Hepatitis B and $\mathrm{C}$ with statistical analysis $(\mathrm{p}>0.05)$. No significant differences in allele frequencies for any polymorphism were observed between patients and controls, although the G allele was more frequent in the patient groups $(\mathrm{p}>0.05)$ (Table 1$)$.

\section{Chronic Hepatitis B}

Overall 70 patients (40 male, 30 female) patients at the mean age of $43.17 \pm 11.94$ who underwent liver biopsy with the diagnosis of Chronic hepatitis B were included in the study. 
54 patients were found to have (77.14\%) GG genotype, 8 (11.43\%) GA genotype, and 8 (11.43\%) AA genotype.

In the comparison of presence of A allele and absence of A allele groups, it was determined that patients in Group-II, high fibrosis score group, has a higher frequency of presence A allele with a difference approaching near significance $(\mathrm{p}=0.052)$. In parallel to these results, in the comparison in terms of $\mathrm{G}$ and $\mathrm{A}$ alleles between two groups, hepatitis B patients in Group-II, group with high fibrosis score, were found to have significantly higher frequency of A alleles $(\mathrm{p}=0.027)$ (Table 2$)$.

\section{Chronic Hepatitis $C$}

Overall 30 patients (17 female, 13 male) patients at the mean age of $45.8 \pm 14.5$ were included in the study. 19 patients had (63.3\%) GG genotype, 8 (26.6\%) GA genotype, and $3(10.1 \%)$ AA genotype. In terms of presence of A allele, no significant difference was found between three groups. Also, no difference was found between presence A allele and absence A allele groups also. No significant difference was found between two groups in terms of the frequency of $\mathrm{G}$ and $\mathrm{A}$ alleles $(\mathrm{p}>0.05)$ (Table 3).

\section{DISCUSSION}

The functions of MBL are complement system activation, regulation of apoptosis and also opsonization and modulation of inflammation(5). MBL is coded by $M B L 2$ gene located on Chromosome 10 (10q11.2-q21) and contains four exons. Polymorphisms in exon 1 and promoter regions of $M B L 2$ gene were reported to be associated with lower MBL serum levels. It is known that structural polymorphisms in the first exon of the gene such as codon 52,54 and 57 cause also functional deficiency by impairing the oligomerization of protein(8). 
Therefore, these structural polymorphisms influencing MBL serum levels may lead to the predisposition to viral and bacterial diseases.

Personal factors influencing the development of liver damage in viral hepatitis are as follows: sex, age, ethnic origin, duration of infection, alcohol intake, dual infections with $\mathrm{HIV} / \mathrm{HBV} / \mathrm{HCV}$ and genotype of the virus. In addition, the importance of the immune state of the person is one of the issues recently addressed. In relation to this issue, polymorphisms of genes coding pro-inflammatory cytokines, vitamin D receptor and HLA types are being under consideration.

It is known that primarily Th1 response develops against hepatitis B infection and in cases when response remains inadequate; the disease enters the process of becoming chronic. In various studies, the importance of innate immune response in viral infections was stressed, as in all other infectious conditions(9). It has been suggested that MBL plays part in the clearance of virus through direct effect of complement activation in hepatitis B infection and in addition decreases inflammatory damage in liver tissue by reducing the release of proinflammatory cytokines(10,11).

The effect of MBL2 gene polymorphism and MBL serum levels on the course of chronic hepatitis B has been reported so far in few studies. In spite of the differences in cohort characteristics, experimental approaches and in investigated polymorphisms, many of these studies found relation between the degree of disease caused by HBV and polymorphisms in $M B L 2$ gene and resultant low MBL levels. In various studies, an association was found between $M B L 2$ polymorphisms and viral persistence, advanced disease, HBV acquisition and survival in fulminant hepatic disease. However, there are also studies suggesting the contrary.

The relation between $M B L 2$ gene polymorphisms and persistence of HBV was first revealed in 1996(12). In this study, they showed in Caucasian patients an association of the codon 52 polymorphism of the $M B L 2$ gene with persistent HBV infection. In a study carried 
out in 1999, it was maintained that codon 54 polymorphism was influential in the persistence and progression of disease and it was also shown that the probability of the development of symptomatic cirrhosis and spontaneous bacterial peritonitis was higher in adult HBV patients with codon 54 polymorphism. Thus, it was proposed that if people with polymorphism are identified, follow-up approaches may change, and prophylactic treatment against infections may be beneficial to these patients(13). In a study carried out in Vietnam, codon 54 polymorphism were found to be more frequent in the people who have acute Hepatitis B. In the same study, an association was found between codon 54 polymorphism and high viral load and transaminase values and it was suggested that MBL was directly effective in HBV clearance(14). Another study showed that MBL polymorphisms decrease survival in fulminant hepatitis caused by Hepatitis B virus. It was also thought that serum MBL levels may be used as a predictive factor for survival in these patients(15).

Overall, 527 patients were examined in an interesting study and it was demonstrated that in people without polymorphism, Hepatitis B infection resulted in natural immunity while in cases with codon 54 polymorphism and low serum MBL levels, persistent disease occurred significantly more common. Investigators suggested that low chronic MBL levels are related to persistence of disease(16). In another study, 320 HBsAg carriers, 199 HBV-related cirrhosis and hepatocellular cancer (HCC) patients, and $87 \mathrm{HBV}$ infection patients with undergoing spontaneous seroconversion were compared with respect to $M B L 2$ gene polymorphisms(17). They did not find any relation between $M B L 2$ gene polymorphism and MBL level in those who are HBsAg carriers, who have spontaneous seroconversion and in healthy controls. However, in patients who have MBL genotypes with presence of A allele, the risk of advanced disease (cirrhosis, HCC, etc.) was found to be increased three fold.

In contrast, some publications resulted otherwise. In 1998, codon 52 and 54 polymorphisms were found to have no association with chronic hepatitis B in a German 
study(18). Similarly in a study carried out in 2005 in Korea, no association was seen between codon 54 polymorphism and clearance of hepatitis $\mathrm{B}$ infection or progression of chronic Hepatitis B infection(19).

In spite of the presence of a few articles arguing for the opposite view, the idea that polymorphisms causing a decrease in serum level of MBL have an adverse effect on the prognosis of Hepatitis B infection is becoming more dominant.

In our study, 54 patients were found to have (77.14\%) GG genotype, 8 (11.43\%) GA genotype, and $8(11.43 \%)$ AA genotype in hepatitis B group. High fibrosis, score group, has a higher rate of codon 54 polymorphism with a difference approaching significance $(p=0.052)$. In parallel to these results, in the comparison in terms of $G$ and $A$ alleles between two groups, patients in Group-II, group with high fibrosis score, were found to have significantly higher prevalence of A alleles $(\mathrm{p}<0.05)$.

The role of MBL in Chronic Hepatitis $\mathrm{C}$ has not been clearly defined in studies performed to date. In a few studies, it was thought that high MBL levels have a positive correlation with pathology and response to treatment. These studies are different in terms of cohort characteristics, classification of cases and the investigated MBL2 gene polymorphisms. In a study published in 1998, it was established that homozygote genotype in codon 54 was associated with weak response to interferon treatment in patients with chronic Hepatitis $\mathrm{C}(20)$. In another study performed in 2000,52 patients with HCV infection were compared with 50 healthy controls and patients with codon 54 polymorphism were found to have more advanced disease and it was thought that MBL may be one of the factors influencing the course of HCV infection(21).

In 2006, 100 hepatitis C patients were compared with control group and codon 54 polymorphism was found to be more frequent in patient group and it was concluded that codon 54 polymorphism may be a risk factor for $\mathrm{HCV}$ infection in an another study(22). 
$M B L 2$ gene polymorphisms was found to occur at a significantly higher rate in cases with $\mathrm{HCV}$ infection than healthy controls in more recent study and it was also determined that response to Pegylated interferon (Peg-IFN) and Ribavirin treatment was lower in cases with polymorphism, even though the difference was not statistically significant(23). Another study published in 2008 stated that polymorphisms in MBL2 gene exon-1 region were associated with low MBL levels and the progression of $\mathrm{HCV}$ infection towards liver inflammation and fibrosis (24). And also $M B L 2$ gene polymorphism was suggested to be directly related to progression of chronic hepatitis $\mathrm{C}$ and response to Peg-IFN therapy(25). In a most recent study; it was reported that $M B L 2$ variant alleles and hence low MBL levels increase the predisposition to $\mathrm{HCV}$ infection, and that HYO haplotype is associated with the severity of fibrosis(26). In a study comparing MBL related serine protease-1 complex (MBL/MASP-1) activity in patients with $\mathrm{HCV}$ infection with that in the healthy control group, positive correlation was found between the liver fibrosis and the MBL serum levels. In addition, a significant relation was found between the MBL/MASP-1 activity and the HCV-related liver fibrosis(9).

In a few studies, no significant association was found between $M B L 2$ gene polymorphisms and accordingly low MBL levels, and predisposition to $\mathrm{HCV}$ infection, disease progression and response to treatment $(27,28)$

In the present study, among patients in chronic hepatitis C group, 19 had (63.3\%) GG genotype, $8(26.6 \%)$ GA genotype and $3(10.1 \%)$ AA genotype. There was no statistically significant difference between fibrosis groups in terms of the presence of A allele.

It is difficult to determine the role of MBL in viral hepatitis accurately since $M B L 2$ gene polymorphisms and MBL serum levels vary significantly between and within populations. To our knowledge, there is no study in the literature which investigates the association between $M B L 2$ gene polymorphisms and liver histopathology directly. In the 
present study, among chronic hepatitis B patients, fibrosis was found to be higher in presence of A allele carrying group, suggesting that individuals with these polymorphisms should be examined earlier for liver damage and if necessary for treatment.

Although it is accepted that MBL plays a part in the course of HBV and HCV infections, larger studies investigating the association between MBL levels and disease progression and treatment are required. It is suggested that other single nucleotide polymorphisms in exon1 and promoter regions of $M B L 2$ gene should be investigated and accordingly it is hoped that with the determination of changing MBL serum levels, information predictive of the course of disease and response to treatment can be obtained.

\section{AUTHORS' NOTE}

All of the authors declare that they have no conflicts of interest regarding this paper. 


\section{REFERENCES}

1. Terai I, Kobayashi K, Matsushita M, Miyakawa H, Mafune N, Kikuta H. Relationship between gene polymorphisms of mannose-binding lectin (MBL) and two molecular forms of MBL. Eur J Immunol 2003;33:2755-63.

2. Dumestre-Perard C, Ponard D, Arlaud GJ, Monnier N, Sim RB, Colomb MG. Evaluation and clinical interest of mannan binding lectin function in human plasma. Mol Immunol 2002; 39: 465-73.

3. Fujita T, Matsushita M, Endo Y. The lectin-complement pathway-its role in innate immunity and evolution. Immunol Rev 2004; 1 98: 185-202.

4. Eisen DP, Minchinton RM. Impact of mannose-binding lectin on susceptibility to infectious diseases. Clin Infect Dis 2003; 37: 1496-1505.

5. Garred P, Larsen F, Madsen HO, Koch C. Mannose-binding lectin deficiencyrevisited. Mol Immunol 2003; 40:73-84.

6. Ishak K, Baptista A, Bianchi L, Callea F, De Groote J, Gudat F, et al. Histological grading and staging of chronic hepatitis. J Hepatol 1995; 22: 696-9

7. Vardar F, Pehlivan S, Onay H, Atlihan F, Güliz N, Ozkinay C, et al. Association between mannose binding lectin polymorphisms and predisposition to bacterial meningitis. Turk J Pediatr 2007;49: 270-3

8. Madsen HO, Garred P, Thiel S, Kurtzhals JA, Lamm LU, Ryder LP, et al. Interplay between promoter and structural gene variants control basal serum level of mannanbinding protein. J Immunol 1995;155: 3013-20.

9. Brown KS, Ryder SD, Irving WL, Sim RB, Hickling TP. Mannan binding lectin and viral hepatitis. Immunology Letters 2007;108:34-44.

10. Gerlich WH, Lu X, Heermann KH. Studies on the attachment and penetration of hepatitis B virus. J Hepatol 1993;17 Suppl 3:S10-4 
11. Saevarsdottir S, Vikingsdottir T, Valdimarsson H. The potential role of mannanbinding lectin in the clearance of self-components including immüne complexes. Scand J Immunol 2004;60:23-9.

12. Thomas HC, Foster GR, Sumiya M, McIntosh D, Jack DL, Turner MW, et al. Mutation of gene of mannose-binding protein associated with chronic hepatitis B viral infection. Lancet 1996;348:1417-9.

13. Yuen MF, Lau CS, Lau YL, Wong WM, Cheng CC, Lai CL, et al. Mannose binding lectin gene mutations are associated with progression of liver disease in chronic hepatitis B infection. Hepatology 1999;4:1248-51.

14. Song Le H, Binh VQ, Duy DN, Kun JF, Bock TC, Kremsner PG, et al. Mannosebinding lectin gene polymorphisms and hepatitis B virüs infection in Vietnamese patients. Mutat Res 2003;12:119-25.

15. Hakozaki Y, Yoshiba M, Sekiyama K, Seike E, Iwamoto J, Mitani K, et al. Mannosebinding lectin and the prognosis of fulminant hepatic failure caused by HBV infection. Liver 2002;1:29-34.

16. Thio CL, Mosbruger T, Astemborski J, Greer S, Kirk GD, O'Brien SJ, et al. Mannose binding lectin genotypes influence recovery from hepatitis B virus infection. J Virol 2005;79: 9192-6.

17. Chong WP, To YF, Ip WK, Yuen MF, Poon TP, Wong WH, et al. Mannose-binding lectin in chronic hepatitis B virus infection. Hepatology 2005;5:1037-45.

18. HohlerT, Wünschel M, Gerken G, Schneider PM, Meyer zum Büschenfelde KH, Rittner $\mathrm{C}$, et al. No association between mannose-binding lectin alleles and susceptibility to chronic hepatitis B virus infection in German patients. Exp Clin Immunogenet 1998;15:130-3. 
19. Cheong JY, Cho SW, Lim SK, Shin DH, Yoon SK, Lee JE, et al. Lack of association between hepatitis B virus infection and polymorphism of mannose-binding lectin gene in Korean population. J Korean Med Sci 2005;20:65-9.

20. Matsushita M, Hijikata M, Ohta Y, Iwata K, Matsumoto M, Nakao K, et al. Hepatitis $\mathrm{C}$ virus infection and mutations of mannose-binding lectin gene MBL. Arch Virol $1998 ; 143: 645-51$.

21. Sasaki K, Tsutsumi A, Wakamiya N, Ohtani K, Suzuki Y, Watanabe Y, et al. Mannose-binding lectin polymorphisms in patients with hepatitis $\mathrm{C}$ virus infection. Scand J Gastroenterol 2000;35:960-5.

22. Somi MH, Asgharsadeh M, Farhang S, Naseri AR, Mohammadzadeh M, Nasiri B, et al. Association of Mannose Binding Lectin Polymorphism with Hepatitis C Infection in Northwest of Iran. Hepatitis Monthly 2006;6:53-7.

23. Segat L, Silva Vasconcelos LR, Montenegro de Melo F, Santos Silva B, Arraes LC, Moura $\mathrm{P}$, et al. Association of polymorphisms in the first exon of mannose binding lectin gene (MBL2) in Brazilian patients with $\mathrm{HCV}$ infection. Clin Immunol $2007 ; 124: 13-7$

24. Koutsounaki E, Goulielmos GN, Koulentaki M, Choulaki C, Kouroumalis E, Galanakis E. Mannose-binding Lectin MBL2 Gene Polymorphisms and Outcome of Hepatitis C Virus-infected Patients. J Clin Immunol 2008;28:495-500.

25. Alves Pedroso ML, Boldt AB, Pereira-Ferrari L, Steffensen R, Strauss E, Jensenius JC, et al. Mannan-binding lectin MBL2 gene polymorphism in chronic hepatitis C: association with the severity of liver fibrosis and response to interferon therapy. Clin Exp Immunol 2008;152:258-64.

26. Halla MC, do Carmo RF, Silva Vasconcelos LR, Pereira LB, Moura P, de Siqueira ER, et al. Association of hepatitis C virus infection and liver fibrosis severity with the 
variants alleles of MBL2 gene in a Brazilian population. Hum Immunol 2010;71:8837.

27. Kilpatrick DC, Delahooke TE, Koch C, Turner ML, Hayes PC. Mannan binding lectin and hepatitis C infection. Clin Exp Immunol 2003;132:92-5

28. Vallinoto AC, da Silva RF, Hermes RB, Amaral IS, Miranda EC, Barbosa MS, et al. Mannose-binding lectin gene polymorphisms are not associated with susceptibility to hepatitis $\mathrm{C}$ virus infection in the Brazilian Amazon region. Human Immunol 2009;70:754-7. 
Table 1: MBL2 gene codon 54 allele frequency and genotype distribution among chronic hepatitis patients and control group

\begin{tabular}{llll}
\hline \multicolumn{1}{c}{ Genotype/Allele } & $\begin{array}{c}\text { Patient Group } \\
\text { (Chronic hepatitis B and C) } \\
(\mathbf{n = 1 0 0 )}\end{array}$ & $\begin{array}{c}\text { Control Group } \\
(\mathbf{n = 1 0 0})\end{array}$ & p-value \\
\hline G/G Genotype & 73 & 63 & 1 (Reference) \\
G/A Genotype & 16 & 19 & 0.92 \\
A/A Genotype & 11 & 18 & 0.59 \\
& & & \\
G allele frequency (\%) & 81 & 78 & 0.59 \\
A allele frequency (\%) & 19 & 22 & \\
& & & \\
\hline
\end{tabular}

Table 2: Analysis of genotypes and alleles according to chronic hepatitis B fibrosis groups

\begin{tabular}{llll}
\hline Hepatitis B & $\begin{array}{l}\text { Group-I } \\
\text { (Fibrosis Score } \leq 3)\end{array}$ & $\begin{array}{l}\text { Group-II } \\
\text { (Fibrosis Score } \geq 4)\end{array}$ & p-value \\
\hline $\begin{array}{l}\text { GG genotype } \\
\text { (n) (\%) }\end{array}$ & $48(81 \%)$ & $6(54 \%)$ & \\
$\begin{array}{l}\text { GA genotype } \\
\text { (n) (\%) }\end{array}$ & $6(10 \%)$ & $2(18 \%)$ & 0.11 \\
$\begin{array}{l}\text { AA genotype } \\
\text { (n) }(\%)\end{array}$ & $5(9 \%)$ & $3(28 \%)$ & \\
$\begin{array}{l}\text { Absense A allele(GG) } \\
\text { (n) (\%) }\end{array}$ & $48(81 \%)$ & $6(54 \%)$ & 0.052 \\
$\begin{array}{l}\text { Presense A allele(GA+AA) } \\
\text { (n) (\%) }\end{array}$ & $11(19 \%)$ & $5(46 \%)$ & \\
$\begin{array}{l}\text { G allele } \\
(n)(\%)\end{array}$ & $102(86 \%)$ & $14(64 \%)$ & 0.027 \\
$\begin{array}{l}\text { A allele } \\
(n)(\%)\end{array}$ & $16(14 \%)$ & $8(36 \%)$ & \\
\hline
\end{tabular}


Table 3: Analysis of genotypes and alleles according to chronic hepatitis $\mathrm{C}$ fibrosis groups

\begin{tabular}{cccc}
\hline Hepatitis C & $\begin{array}{c}\text { Group-I } \\
\text { (Fibrosis score } \leq 3)\end{array}$ & $\begin{array}{c}\text { Group-II } \\
\text { (Fibrosis score } \geq 4)\end{array}$ & p-value \\
\hline $\begin{array}{c}\text { GG genotype } \\
\text { (n) }(\%)\end{array}$ & $16(64 \%)$ & $3(60 \%)$ & \\
$\begin{array}{c}\text { GA genotype } \\
\text { (n) (\%) }\end{array}$ & $6(24 \%)$ & $2(40 \%)$ & 0.60 \\
$\begin{array}{c}\text { AA genotype } \\
\text { (n) (\%) }\end{array}$ & $3(12 \%)$ & $0(0 \%)$ & \\
$\begin{array}{c}\text { Absense A allele(GG) } \\
\text { (n) (\%) }\end{array}$ & $16(64 \%)$ & $3(60 \%)$ & 0.86 \\
$\begin{array}{c}\text { Presense A allele(GA+AA) } \\
\text { (n) (\%) }\end{array}$ & $9(36 \%)$ & $2(40 \%)$ & \\
$\begin{array}{c}\text { G allele } \\
\text { (n) (\%) }\end{array}$ & $38(76 \%)$ & $8(80 \%)$ & 0.78 \\
$\begin{array}{c}\text { A allele } \\
\text { (n) (\%) }(\%)\end{array}$ & $12(24 \%)$ & $2(20 \%)$ & \\
\hline
\end{tabular}

